Article

\title{
Past, Present and Future of Hay-making Structures in Europe
}

\author{
Jana Špulerová ${ }^{1, *} \mathbb{0}$, Alexandra Kruse ${ }^{2}$, Paola Branduini ${ }^{3}$, Csaba Centeri ${ }^{4} \oplus$, Sebastian Eiter ${ }^{5}$, \\ Viviana Ferrario ${ }^{6}$, Bénédicte Gaillard ${ }^{7}$, Fausto Gusmeroli ${ }^{8}$, Suzan Jurgens ${ }^{9}$, Drago Kladnik ${ }^{10}$, \\ Hans Renes ${ }^{11,12}$, Michael Roth ${ }^{13}$, Giovanni Sala ${ }^{14}$, Hanne Sickel ${ }^{5}$, Maurizia Sigura ${ }^{15}$, \\ Dagmar Štefunková ${ }^{1}$ (D), Kari Stensgaard ${ }^{5}$, Peter Strasser ${ }^{16}$, Cosmin Marius Ivascu ${ }^{17}$ \\ and Kinga Öllerer 18,19 (iD) \\ 1 Institute of Landscape Ecology of the Slovak Academy of Sciences, Štefanikova 3, 81499 Bratislava, Slovakia; \\ dagmar.stefunkova@savba.sk \\ 2 Insitu World Heritage Consulting, 10bis, rue du Haras, 78530 Buc, France; akruse@whconsult.eu \\ 3 Politecnico di Milano, Piazza Leonardo da Vinci 32, 20133 Milano, Italy; paola.branduini@polimi.it \\ 4 Szent István University, Páter Károly utca 1, 2103 Gödöllő, Hungary; centeri.csaba@mkk.szie.hu \\ 5 NIBIO-Norwegian Institute of Bioeconomy Research, Division of Survey and Statistics, P.O. Box 115, 1431 Ås, \\ Norway; sebastian.eiter@nibio.no (S.E.); hanne.sickel@nibio.no (H.S.); kari.stensgaard@nibio.no (K.S.) \\ 6 IUAV, University of Venice, 30135 Venezia, Italy; viviana.ferrario@iuav.it \\ 7 BG Consulting in World Heritage Conflict Management, Ave du Belvédère 199, 83380 Les Issambres, France; \\ benedicte@gaillard-consulting.com \\ 8 Fondazione Fojanini di Studi Superiori, Via Valeriana 32, 23100 Sondrio, Italy; fausto.gusmeroli@gmail.com \\ 9 Independent Researcher, 7325 NK Apeldoorn, The Netherlands; s.m.jurgens@chello.nl \\ 10 Anton Melik Geographical Institute ZRC SAZU, Gosposka ulica 13, 1000 Ljubljana, Slovenia; \\ drago.kladnik@zrc-sazu.si \\ 11 Faculty of Geosciences, Utrecht University, 3508 TC Utrecht, The Netherlands; j.renes@uu.nl \\ 12 Faculty of Humanities, Vrije Universiteit Amsterdam, 1081 HV Amsterdam, The Netherlands \\ 13 School of Landscape Architecture, Environmental and Urban Planning, Nürtingen-Geislingen University, \\ Schelmenwasen 4, 72622 Nürtingen, Germany; michael.roth@hfwu.de \\ 14 Scienze Cognitive e Processi Decisionali, University of Milan, Via Bigli 11, 20121 Milan, Italy; \\ giovanni.sala.studio@gmail.com \\ 15 Department of Agricultural, Food, Environmental and Animal Science, University of Udine, \\ Via delle Scienze 206, 33100 Udine, Italy; maurizia.sigura@uniud.it \\ 16 Center for Cultural Property Protection and Center for Architectural Heritage and Infrastructure, \\ Danube University Krems, Dr.-Karl-Dorrek-Straße 30, 3500 Krems, Austria; Peter.Strasser@donau-uni.ac.at \\ 17 Department of Taxonomy and Ecology, Faculty of Biology and Geology, Babeș-Bolyai University, \\ Clinicilor Street 5-7, 400006 Cluj-Napoca, Romania; ivascu.cosmin@hotmail.com \\ 18 Institute of Biology Bucharest, Romanian Academy, Spl. Independenței 296, 060031 Bucharest, Romania; \\ kinga.ollerer@gmail.com \\ 19 Institute of Ecology and Botany, MTA Centre for Ecological Research, Alkotmány u. 2-4, \\ 2163 Vácrátót, Hungary \\ * Correspondence: jana.spulerova@savba.sk
}

Received: 23 August 2019; Accepted: 26 September 2019; Published: 10 October 2019

Abstract: Hay-making structures are part of the agricultural landscape of meadows and pastures. Hay meadows are still used and found all over Europe, but their distribution patterns as well as their characteristics and regional features depend on geographical area, climate, culture, and intensity of agriculture. Intensively used hay meadows are the most dominant, using heavy machinery to store hay mostly as rounded or square bales. Traditional hay-making structures represent structures or constructions, used to quickly dry freshly cut fodder and to protect it from humidity. The 'ancient' forms of traditional hay-making structures are becoming a relic, due to mechanisation and the use of new technologies. Both the need for drying hay and the traditional methods for doing so were similar across Europe. Our study of hay-making structures focuses on their current state, their 
development and history, current use and cultural values in various European countries. Regarding the construction and use of hay-making structures, we have distinguished three different types, which correlate to natural and regional conditions: (1) temporary hay racks of various shapes; (2) hay barracks, a special type of shelters for storing hay and (3) different types of permanent construction and buildings for drying and storing hay. Hay-making structures have been mostly preserved in connection with traditional agricultural landscapes, and particularly in the more remote regions or where associated with strong cultural identity.

Keywords: hayrack; meadows; hay barrack; permanent construction; cultural landscape

\section{Introduction}

Grasslands cover more than a third of the European agricultural area and are very diverse in terms of management, yield and biodiversity value. Lesschen et al. [1] distinguish between production grasslands, which mainly produce fodder, and semi-natural grasslands, which provide a large range of ecosystem services, including biodiversity. A large number of definitions exist in the scientific literature, policies and statistical surveys making it difficult to get comparable statistics about the actual extent of hay production in Europe. What we can say is that landscapes which are connected to hay production do exist all over Europe and even if their extent in hectares and the production process has changed over the years, they still have significant importance, many of them being recognised as high nature value (HNV) landscapes.

Structures for making and storing of hay are part of the agricultural landscape of meadows and pastures and their distribution patterns as well as their characteristics and regional features depend on geographical area, climate, culture, and intensity of agriculture. They could—and often still can-be found in regions traditionally specialised in animal husbandry as well as in regions of mixed farming. They are feature of a cultural landscape cultivated by man and their aim was to store hay, necessary for the survival of farm animals during winter or even, in dry period during other seasons. Hay production and harvest, known as "making hay", "haymaking", or "doing hay", involves a multiple step process: cutting, drying or "curing", raking, processing, and storing [2]. In some regions, e.g., in the Alps and the Carpathians, the preparatory work to be done also includes clearing the fields of stones, raking, activating the irrigation system, and activities for the maintenance and restoration of the quality of the meadow, like fertilizing (manuring) and scattering hayseeds [3-5]. Both the need for drying hay and the traditional methods for doing so were similar across Europe.

The various structures related to the process of hay-making, both-temporary and permanent, reflect a vast traditional ecological knowledge associated with making and storing hay. Temporary structures and constructions occur in many different forms according to their geographic origin and scope for quick drying of freshly cut fodder and/or protecting it for longer periods from humidity and wild animals. No matter which form the temporary structures for drying in the field have, they also have in common that they must prevent the formation of undesirable molds and fungi. The great variety of different regional solutions is impressive and increases the cultural value of these landscapes, as the traditional management of hay-making represents an integral part of the European cultural heritage. The permanent structures, such as barns, etc., are also diverse in form, material and use, according to their location. This also includes permanent wooden buildings on the meadows themselves, e.g., in the lower parts of the Alps and in the Carpathians. This article deals only with the traditional structures located within the hay-making landscapes. We did not pay attention to hay storage constructions which are part of a stable or a farmer's house, as an annex or upper floor.

The pre-industrial techniques of hay-making and storage are now less used and less present, due to mechanisation and the use of other new technologies. Mechanisation started in the early 20th century, both in the plains and in the mountain areas. The period from the 1950s onwards is connected to terms 
such as industrialization of agriculture and the "Green Revolution" and featured substitution of human labour by modern energy inputs, while livestock continued to rely greatly on domestic biomass [6]. Intensification of post-war agriculture in Central European countries like Hungary, Czechia, Slovakia, Romania, Bulgaria and the former East Germany has been linked to collectivisation of land from private to (socialist) state ownership causing a decline in the spatial heterogeneity of the landscape and bringing about the loss of almost all the traditional pre-industrial agricultural landscapes, and much of the associated traditional knowledge [4,7-11]. In most countries in Western Europe, modernization took place under the Common Agriculture Policy and in many regions included land consolidation projects that, although more gradual, had effects on historic landscapes that were comparable with the Central European collectivisations.

At the present time, intensively used hay meadows are dominant, with farmers using heavy machinery to store hay in large modern haylofts, mostly as rounded or square bales of hay weighing up to $1,400 \mathrm{~kg}$. The decline of traditional hay-making was also hastened by the introduction of silage, from either permanent silos or round bales, during the 20th century that increased the farmers' flexibility in coping with uncertainty associated with environmental factors [12]. While in Austria in 1988 exactly 77 grass silage balls had been produced, 10 years later 4.5 Mio balls and in 20065.6 Mio silage balls were pressed. In mountain regions, silage is used in $95 \%$ of pastures, on $70 \%$ so called "best soils" [13]. The exceptions are the regions with rather extreme natural conditions, or those from the more remote areas, inaccessible with heavy machinery, where hay-making structures have been preserved.

Our study of hay-making structures focuses on: (1) their current state in various European countries, (2) understanding their development and history, and (3) the drivers, which affect their continued use today, and (4) the values they have for society, which could help with preserving and keeping this traditional system in use.

\section{Materials and Methods}

The research is part of a European agricultural landscape classification project [14] that is focused on special agricultural landscape types, that are about to vanish due to abandonment or homogenisation, including economic marginalisation of locations. Data was collected by a group of experts, who filled in a questionnaire that was developed by the EUCALAND network (http://eucaland.net/) for compiling the characteristics of different types of agricultural landscape to be included into an e-Atlas [14]. The questionnaire consisted of 10 questions about hay-making structure landscapes on the following: (1) basic information about the specific landscape type in each country; (2) national nomenclatures; (3) occurrence in a map grid; (4) genesis (history) of this type of landscape; (5) occurrence in landscape types; (6) physical geography; (7) present use; (8) connections with, e.g., building type and production type; (9) connections to other specific agricultural activities, functions, values, etc.; and (10) public awareness. Additional data were acquired from national and regional databases, atlases, bibliographic sources, etc.

Our methodological approach focused on the classification of the main types of hay-making structures, understanding their development and distribution around Europe and studying factors which influence their preservation, present use, and significance and value for society, and which could help to maintain their use. All observed types of hay-making structures were classified on the basis of their structure and use. In the next step, the map of the distribution of individual types was drawn up based on the partners' knowledge. The current use status and value of hay-making structures was evaluated using other information from the questionnaire (questions 7-9). An additional survey was carried out, which focused on cultural ecosystem services provided by landscapes with hay-making structures, e.g.,:

- as part of the cultural heritage and so treated in Spatial/Environmental planning, Landscape Plans, Local Action Plans and/or Guiding Principles for local groups, serving as national icons or regional symbols in a tourism context;

- maintenance and revival of tradition during actions, events, feast and festivals; 
- new uses, e.g., storage of other materials, or rebuilding into hay hotels, holiday flats, or apartments, or residential houses;

- educational value (ethnological, biological, cultural, historical, etc.);

- aesthetic value, attractiveness and inspiration for artists-literature, painting, architecture, photography or a combination thereof.

\section{Results}

\subsection{The Study Area, Regional Distribution and Terminology}

The survey of hay-making structures was conducted in 17 European countries, covering different biogeographical regions (Table 1). In the past, hay meadows existed all over Europe, even in the floodplains of rivers and streams and on less fertile soils. Non-manured or fertilized hay meadows are considered as a cultural landscape feature of special value in terms of biological diversity $[15,16]$. However, the number and area covered by such hay meadows decreased dramatically over the course of the last century $[17,18]$ and this trend continues today - the average land cover of grassland within European Union countries decreased from $22.3 \%$ in 2009 to $20.5 \%$ in 2015 [19]. Extensification of grasslands after 1990 was greatest in Czechia, Germany, Spain, and Ireland [20]. Areas, which are difficult to access for increasingly large agricultural machinery, have been abandoned and become subject to woodland regrowth, while other areas have been intensified to increase yields. 
Table 1. Characteristic of meadow landscapes with hay-making structures in different countries.

\begin{tabular}{|c|c|c|c|c|}
\hline & $\begin{array}{l}\text { Grassland Cover } \\
\quad(\%)[19]\end{array}$ & $\begin{array}{l}\text { Biogeographical } \\
\text { Region [21] }\end{array}$ & $\begin{array}{l}\text { Local Regional Name for } \\
\text { Hay-making Structures }\end{array}$ & $\begin{array}{l}\text { Present State, Management and Other } \\
\text { Particularities of Hay-making Structures }\end{array}$ \\
\hline Austria (AT) & 24.7 & Continental Alpine & $\begin{aligned} \text { heubarge } & =\text { hay barrack } \\
\text { triste } & =\text { hay pile }\end{aligned}$ & $\begin{array}{l}\text { Hay-making structures are preserved in the mountains } \\
\text { but only where machines cannot be used, permanent } \\
\text { structures are mostly abandoned. Connected to } \\
\text { transhumance in the Alps, "Winterheuzug" = } \\
\text { common work of men (during World War I also } \\
\text { women) to transport the hay down to the valley in } \\
\text { January. Some small plots in the mountains are used } \\
\text { to provide fresh hay for wild animals that would } \\
\text { otherwise damage the forest by eating small trees. }\end{array}$ \\
\hline Belgium & 31 & Atlantic Continental & $\begin{array}{c}\text { veldschuur, Hollandse schuur, } \\
\text { engelse schuur, schuiver, } \\
\text { hooischuur, (Engelse) mijt }= \\
\text { hay barrack }\end{array}$ & $\begin{array}{l}\text { The hay barrack in Flanders is a reintroduction, as is } \\
\text { shown by the names that are not derived from the old } \\
\text { 'berg' names [22]. Flemish hay barracks are called } \\
\text { 'paalschuur' in literature, but that is an artificial name. } \\
\text { In Wallonia the hay barrack can be found in the } \\
\text { mountainous area. }\end{array}$ \\
\hline Bosnia & & $\begin{array}{l}\text { Alpine Continental } \\
\text { Mediterranean }\end{array}$ & $\begin{array}{l}\text { broch, oborog, oborih }= \\
\text { hay barrack }\end{array}$ & $\begin{array}{l}\text { Existed in the Banja Luka region, but no longer in use. } \\
\text { They were owned only by immigrants originally from } \\
\text { Czechia, but who had moved to Ukraine before } \\
\text { immigrating in Bosnia. Haystacks with a central pole } \\
\text { and tripods for drying hay are common in Bosnia. }\end{array}$ \\
\hline Czechia & 22.3 & Continental Pannonian & $\begin{array}{c}\text { sušák sena = hay drying } \\
\text { structure, kopa, küpa, kopka, } \\
\text { kopice, kopen, kopenec = haystack, } \\
\text { svinka, svině = extended } \\
\text { haystack like pig, kůly, trojáky, } \\
\text { štangle, Áčka = wooden hay } \\
\text { stick, ostrva = wooden hay } \\
\text { structrure, oboroh, brah }= \\
\text { hay barrack }\end{array}$ & $\begin{array}{l}\text { Traditional haymaking is disappearing and being } \\
\text { replaced by hay bales. A few examples can be found } \\
\text { due to efforts to preserve traditions (hay-making } \\
\text { camps and festivals) and biodiversity protection } \\
\text { (NGO, nature conservation bodies). Nowadays hay } \\
\text { barracks are only to be found in open air } \\
\text { museums (skansen). }\end{array}$ \\
\hline
\end{tabular}


Table 1. Cont.

\begin{tabular}{|c|c|c|c|c|}
\hline & $\begin{array}{c}\text { Grassland Cover } \\
(\%)[19]\end{array}$ & $\begin{array}{l}\text { Biogeographical } \\
\text { Region [21] }\end{array}$ & $\begin{array}{l}\text { Local Regional Name for } \\
\text { Hay-making Structures }\end{array}$ & $\begin{array}{l}\text { Present State, Management and Other } \\
\text { Particularities of Hay-making Structures }\end{array}$ \\
\hline Croatia & & Mediterranean & $\begin{array}{c}\text { trtoja, tetoja }=\text { hay barrack, kopa, } \\
\text { rasa, kvaka, ostrva }=\text { haystack } \\
\text { with central pole, lomnica }= \\
\text { hay heap, plast, plastič, stog }= \\
\text { hay heap }\end{array}$ & $\begin{array}{l}\text { Still in use in Istria, although diminishing as farming } \\
\text { is no longer profitable. Everything changed after } 1990 . \\
\text { By } 1999 \text {, almost } 80 \% \text { of the former farming area (which } \\
\text { covered nearly all of Istria) was no longer } \\
\text { cultivated [23]. }\end{array}$ \\
\hline France & 26.7 & $\begin{array}{c}\text { Atlantic } \\
\text { Mediterranean }\end{array}$ & $\begin{array}{c}\text { les structures de fenaison }= \\
\text { Hay-making structures, mule de } \\
\text { foin = haystacks, meule carrée }= \\
\text { hay barrack }\end{array}$ & $\begin{array}{l}\text { Hay-making still exists, but has lost its former } \\
\text { importance. Today, hay balls or, more often, silage } \\
\text { balls wrapped in plastic are mostly used. }\end{array}$ \\
\hline Germany & 21.9 & Atlantic Continental & $\begin{array}{l}\text { heuschober = haystack, heuballen } \\
=\text { hay bale, rundballen = round } \\
\text { bales, heuwiese = hay meadow, } \\
\begin{aligned} \text { heuboden } & =\text { hayloft, heuberg, barg } \\
& =\text { hay barrack }\end{aligned}\end{array}$ & $\begin{array}{l}\text { Hay production is present all over the country, though } \\
\text { now mainly for horse keeping and small pets, mostly } \\
\text { mechanised, with rectangular or round bales, the latter } \\
\text { being increasingly popular. Only on very steep slopes, } \\
\text { or for heritage and/or biodiversity preservation } \\
\text { reasons, is grass cut manually. Nowadays only a few } \\
\text { modernized hay barracks survive, apart from those in } \\
\text { open air museums. Several side products: Heutee = } \\
\text { hay tea, Heuhotel = Hay hotel, hay considered to have } \\
\text { both health and natural value, festivals with hay } \\
\text { sculptures, thanksgiving feasts }\end{array}$ \\
\hline Hungary & 19.9 & Pannonian & $\begin{array}{c}\text { abora }=\text { hay barrack, szénakazal = } \\
\text { haystack, hay heap, szénaboglya, } \\
\text { boglya = haystack, szénabála = } \\
\text { hay bale, körbála = round bale, } \\
\text { kockabála = cubic bale, } \\
\text { szénakunyhó = hay storage shack }\end{array}$ & $\begin{array}{l}\text { The majority of the structures is on the plains and } \\
\text { related to intensive agriculture. However, small } \\
\text { haystacks appear all over the country, related mostly } \\
\text { to small, extensive farms. These were used on the field } \\
\text { until the end of the 20th century for collecting hay } \\
\text { from smaller areas, subsequently to be taken into the } \\
\text { yard of a farm. There it was piled up in one or two } \\
\text { bigger haystacks ( } 3-5 \mathrm{~m} \text { high). Today these occur only } \\
\text { occasionally, in the hillsides and in the mountainous } \\
\text { areas. Machine produced hay balls covered with } \\
\text { plastic are increasingly used. Hay barracks were once } \\
\text { present in the Upper Tisza region. Nowadays they are } \\
\text { found only in open air museums (skansen). }\end{array}$ \\
\hline
\end{tabular}


Table 1. Cont.

\begin{tabular}{|c|c|c|c|c|}
\hline & $\begin{array}{l}\text { Grassland Cover } \\
(\%)[19]\end{array}$ & $\begin{array}{l}\text { Biogeographical } \\
\text { Region [21] }\end{array}$ & $\begin{array}{l}\text { Local Regional Name for } \\
\text { Hay-making Structures }\end{array}$ & $\begin{array}{l}\text { Present State, Management and Other } \\
\text { Particularities of Hay-making Structures }\end{array}$ \\
\hline Italy & 21.7 & Alpine Continental & $\begin{array}{c}\text { meda }(\text { de fen })=\text { haystack with } \\
\text { central pole, covone = hay stick, } \\
\text { harpfe, arfa, favèr, kèisn, kozolec = } \\
\text { hay stack, liguria: barc }(o)=\text { hay } \\
\text { barrack, scapita, barc = hay } \\
\text { barrack, baita, barco, stali = small } \\
\text { hay storage, hayloft, tabià }= \\
\text { hay storage }\end{array}$ & $\begin{array}{l}\text { In the Alps, most of the permanent hay structures are } \\
\text { preserved; they are part of the traditional mosaic } \\
\text { landscape, but today, they are rarely used for } \\
\text { haymaking. In the Dolomites, tabià are permanent } \\
\text { wooden barns (hay drying + storage + cowshed), } \\
\text { dispersed on the meadows, to be used in the } \\
\text { intermediate seasons, and often placed along the way } \\
\text { to the summer pastures. They are often still in } \\
\text { use [24,25]. Barchi and mede in Veneto still partly in } \\
\text { use, barchi sometimes to store round bales. Liguria: } \\
\text { nowadays no longer in use. Friuli: no more hay } \\
\text { barracks, all gone }\end{array}$ \\
\hline The Netherlands & 36.3 & Atlantic & $\begin{array}{l}\text { opper }=\text { hay heap, hooimijten, } \\
\text { schelven, klampen, ruiters = } \\
\text { temporary structures, hooibergen, } \\
\text { hooischuren = permanent } \\
\text { structures for hay storage, } \\
\text { steltenberg, stoltenberg, schuurberg } \\
\text { = hay barrack with raised floor } \\
\text { and extensions to the side }\end{array}$ & $\begin{array}{l}\text { Specialised hay meadows have mainly disappeared. } \\
\text { Some former 'water meadows' as well as 'blue } \\
\text { grasslands' and other species-rich grasslands have } \\
\text { been preserved, mainly for ecological purposes. Hay } \\
\text { was and is extremely important in the Netherlands, } \\
\text { not only for the abundant dairy cows and, formerly, } \\
\text { draught and war horses but also for export. Grass in } \\
\text { the peat and clay areas was and still is often of } \\
\text { excellent quality. There may have been a few hundred } \\
\text { thousand hay barracks in the 19th and early 20th } \\
\text { century (not only for the storage of hay, though); now } \\
\text { there are no more than around 5,000 left, which are } \\
\text { seldom used for their original purpose if used at all. }\end{array}$ \\
\hline Norway & 19.4 & Boreal & $\begin{array}{c}\text { høysåte, høystakk = stack, } \\
\text { hesjestaur }=\text { wooden stick, hesje } \\
=\text { drying rack, treraje = } \\
\text { horizontal stick, luovvo = } \\
\text { haystack on a platform }\end{array}$ & $\begin{array}{l}\text { Before } 1900 \text { hay was mostly harvested from outfields, } \\
\text { mainly on forest and mountain grasslands, while } \\
\text { infields were reserved for growing cereals. Later on, } \\
\text { hay fodder was also been produced on infields [26]. } \\
\text { Special techniques (e.g., zip-lines for downhill } \\
\text { transport of hay from meadows to barns) and several } \\
\text { types of permanent and semi-permanent structures } \\
\text { existed. Luovvi are used by Saami people. }\end{array}$ \\
\hline
\end{tabular}


Table 1. Cont.

\begin{tabular}{|c|c|c|c|c|}
\hline & $\begin{array}{l}\text { Grassland Cover } \\
\text { (\%) [19] }\end{array}$ & $\begin{array}{l}\text { Biogeographical } \\
\text { Region [21] }\end{array}$ & $\begin{array}{l}\text { Local Regional Name for } \\
\text { Hay-making Structures }\end{array}$ & $\begin{array}{l}\text { Present State, Management and Other } \\
\text { Particularities of Hay-making Structures }\end{array}$ \\
\hline Poland & 22.6 & Continental Alpine & $\begin{array}{l}\text { kopa siana, kopka = hay stack, } \\
\text { ostrew, stóg siana = hay stick, } \\
\text { wiazka siana - hay sheaves, hay } \\
\text { ball, bróg = hay barrack }\end{array}$ & $\begin{array}{l}\text { Small-scale mosaic landscape of grassland and arable } \\
\text { land is still preserved. Special method of making hay } \\
\text { stack by "wiazka siana". Hay barrack are nowadays no } \\
\text { longer in use. }\end{array}$ \\
\hline Romania & 27.1 & $\begin{array}{l}\text { Alpine Continental } \\
\text { Pannonian Stepic }\end{array}$ & $\begin{array}{l}\text { şopron/şopru, fânar, șură, colibă de } \\
\text { fân = (hay) barrack, claie, clanie, } \\
\text { șiră, stog = haystack (with } \\
\text { central pole), par de claie, rudă de } \\
\text { claie, prepeleac, perpeleac, țăpăruie } \\
\text { = the pole of a haystack, } \\
\text { germană = haycock tripod, capră, } \\
\text { gard, capră colibă = hay drying } \\
\text { rack, căpiţă, posori, porssori, } \\
\text { porconi, porcoi, boghiuri = hay } \\
\text { heap, haycock, jărăzi, jirezi = } \\
\text { simple hayrack, colibă = } \\
\text { temporary shack, mărginătură = } \\
\text { gathered hay, but not piled into } \\
\text { a stack or haycock, podină, } \\
\text { fundurei, vatră - pieces of wood } \\
\text { and branches with leaves that } \\
\text { are put around the hay stack } \\
\text { pole and on which the haystack } \\
\text { is built, pătul - a pollarded birch } \\
\text { or beech tree, with only some } \\
\text { branches left to grow, in which a } \\
\text { haystack was built, balot = hay } \\
\text { bale, Hungarian regional names } \\
\text { from Transylvania and } \\
\text { Maramures, szénakunyhó, } \\
\text { gunyhó = hay storage shack } \\
\text { szénaszáritó állvány, kecske, bak = } \\
\text { hay drying rack, ösztörü, } \\
\text { üsztürü, csereklye = branched } \\
\text { rack for drying hay in stacks, } \\
\text { szénaboglya, boglya = haystack, } \\
\text { szénabála, bála = hay bale }\end{array}$ & $\begin{array}{l}\text { Hay barracks and various temporary shacks are still in } \\
\text { use in the Romanian Carpathians (mainly in } \\
\text { Maramureș, Transylvania), although diminishing. } \\
\text { These mountain regions were never very influenced } \\
\text { by Ceauşescu's agricultural policy of intensification } \\
\text { and large-scale farming, thanks to their remoteness } \\
\text { and isolation. Haystacks are common in Romania [3], } \\
\text { but in hilly areas and in the lowlands tend to be } \\
\text { replaced by hay bales, wrapped in plastic. }\end{array}$ \\
\hline
\end{tabular}


Table 1. Cont.

\begin{tabular}{|c|c|c|c|c|}
\hline & $\begin{array}{l}\text { Grassland Cover } \\
\quad(\%)[19]\end{array}$ & $\begin{array}{l}\text { Biogeographical } \\
\text { Region [21] }\end{array}$ & $\begin{array}{l}\text { Local Regional Name for } \\
\text { Hay-making Structures }\end{array}$ & $\begin{array}{l}\text { Present State, Management and Other } \\
\text { Particularities of Hay-making Structures }\end{array}$ \\
\hline Slovakia & 19.5 & Alpine Pannonian & $\begin{array}{l}\text { ostrva, koly = wooden hay stick, } \\
\text { kopy, stohy sena (petrenec, kopenec, } \\
\text { navidl'a, kozák, babiak) = } \\
\text { local/regional names for } \\
\text { haystack, hayrack, oborohy = hay } \\
\text { barracks, sennik = hayloft }\end{array}$ & $\begin{array}{l}\text { Preserved only on small scale farmland, on high steep } \\
\text { slope unsuitable for machinery. They are part of the } \\
\text { cultural heritage: there is related genre of traditional } \\
\text { folk songs called "travnice" [27]. Nowadays, hay } \\
\text { barracks are only to be found in open air } \\
\text { museums (skansen). }\end{array}$ \\
\hline
\end{tabular}
museums (skansen).

ostrv = wooden hay stick, senen kopa $($ kopica $)=$ haystack, ostrnica/preprosti kozolec $=$ hay sticks/simple hayrack, kozolec (kozovc, kozuc) = hayrack, kozolec brez strehe $=$ hayrack without roof, enojni kozolec $=$ single hayrack, stegnejni kozolec $=$

Slovenia 21.7

Alpine (Dinaric) imple st kozolec s plaščem = hayrack with "cloak", dvojni kozolec = double hayrack, toplar $=$ coupled hayrack, kozolec na kozla = "goat" hayrack, prislonjeni kozolec $=$ leaned hayrack, leseni kozolec $=$ wooden hayrack, zidani kozolec $=$

hayloft, bale $=$ round bales

\begin{tabular}{|c|c|c|c|}
\hline Switzerland & Alpine Continental & heuberge $=$ haystack & $\begin{array}{l}\text { Still in use in some remote areas in central Switzerland } \\
(\text { "Heuberge"), theme trails exist. }\end{array}$ \\
\hline Ukraine & $\begin{array}{l}\text { Alpine Continental } \\
\text { Steppic }\end{array}$ & oborih = hay barrack & $\begin{array}{l}\text { Hay barracks are widespread in Western Ukraine, but } \\
\text { are present elsewhere as well. }\end{array}$ \\
\hline
\end{tabular}

Slovenia is called "the land of the hay racks (Dežela kozolcev). Hay racks are widely preserved as a part of the traditional mosaic landscape. With the advent of new techniques in preparing fodder for livestock they are rapidly losing importance, so they are decaying or changing their purpose. They are still very popular as decoration and some of them are being adapted for habitation or purposes of tourism, or even newly constructed for these purposes. The surface area of meadows increased after abandoning fields due to decreased self-sufficiency. The meadows are still widely in use, especially due to the growing importance of stockbreeding; pastures are exposed to afforestation. are present elsewhere as well. 


\subsection{The History and Typology of Hay-Making Structures}

Hay-making structures were developed along with farming methods and they were used with a clear purpose: drying and storing hay for later usage as livestock fodder, and protecting it from moisture, rodents and wild ungulates, vermin [28]. Archeological excavations show possible hay barracks in the Netherlands, dating from the late Roman period. In various geographical and ethnical regions different structures of drying sheds have been developed and implemented [29-34]. The effect of geographical regions is seen in the different names of structures, found in border areas. We can distinguish three main groups of hay-making structures based on their construction and use:

(1) Temporary hayracks of various shapes were particularly widespread in most European regions for drying and temporary storage: e.g., hayracks, sticks, hay heaps, and harpfe, made from wood or metal, or with a roof made of straw, wood, or, more lately, metal (Figure 1).

- Hay heaps or haystacks are the simplest temporary structures to dry fodder in the field, built on a wood pile. Haystacks or haycocks are nothing more than heaps of hay. They may or not have staggered wooden peds (Figure $1(1 \mathrm{~A}, 1 \mathrm{~B})$ ), or they may have some larger wooden frame over which the hay is draped. One type of construction consists of a three to five meters tall spruce or hardwood stake or pole, in some cases with side branches or smooth stake with cross pin (Figure $1(1 \mathrm{C}, 1 \mathrm{D}, 1 \mathrm{E})$ ); another is tripod - a frame consisting of a loose construction of three poles, with the base placed in a triangle shape and bound together at the tops, with horizontal poles bound between the vertical poles (Figure 1(1F)); or pyramidal stands with multiple horizontal battens (Figure $1(1 \mathrm{G})$ ). Sometimes hay is simply piled around a tree. Haystacks are also called haycocks in some dialects of English, or sometimes stokes, shocks, or ricks. They are still very common in many regions, e.g., in Italy (especially in the plane area), Slovakia, Romania, Ukraine and Germany.

- Simple hayracks can be found in the Alpine region (Austria, Italy, Slovenia) and also in Northern (Norway) and Central Europe (Poland, Romania-especially in Maramures). In the traditional design, these structures are made of wood, with two (or more) vertical columns (arfis) and horizontal beams forming the rack on which the fodder leans (perties) (Figure $1(1 \mathrm{H})$ ). In more recent constructions, the horizontal sticks were replaced by strings of steel, and the vertical columns by concrete. The grass was hung on the horizontal sticks or wires. The grass had to be shaken well before being hanged up, often with a hayfork, in thin layers. A wooden rake was used to gather the grass on the ground.

(2) Hay barracks are a special type of hay shelters that are built around one to six, but usually four upright wooden posts, and serve to store large amounts of hay (Figure 2). The original wooden hay barrack had the most elaborate design and greatest variation in the Netherlands. Hay is stacked from the fields under the hay barrack, and removed later during the foddering season. The roof can slide up and down and is locked in place with pegs according to the amount of hay, a feature historically called also a Dutch roof (Figure 2 (2A,2B)). They have been maintained in many parts of the Netherlands, but are ever less frequently used for their original purpose. They are also widespread in Germany, Romania and Flanders (where they are sometimes called 'Dutch') [35], used to exist also in England (imported from the Netherlands; but are no longer used) [35], Italy, Croatia, Bosnia, Poland, Baltics, Belorussia, Czechia, Slovakia and Ukraine. Zimmermann mentions an earlier occurrence of hay barracks in Scandinavia, with the name 'helm' [22]. Outside Europe they are present in the United States and in Canada. The name 'barrack' itself is a North American derivate of the Dutch 'berg' [36]. Several modernizations and inventions have taken place in the hay barracks themselves as well as in handling hay. For example, the Jacob's ladder for hay transporting, the hay grab and the pneumatic hay conveyer (with suction hose and combined with an electric ventilation system) were all developed by the seventies. 
Haylofts or block huts (Figure 2(2C)) are small block huts, generally placed in the highest and most remote meadows. They were used to store hay until the snowfalls, in order to transport hay by sledge. They were widely spread in Carpathian (Slovakia, Romania) and in the Austrian, Italian and Swiss Alps (Figure 3). Today only few are still in use and either have been abandoned (Carpathians), or are used for leisure purposes (Alps). Comparable stone-built buildings for hay storage exist in the Pennines in England.

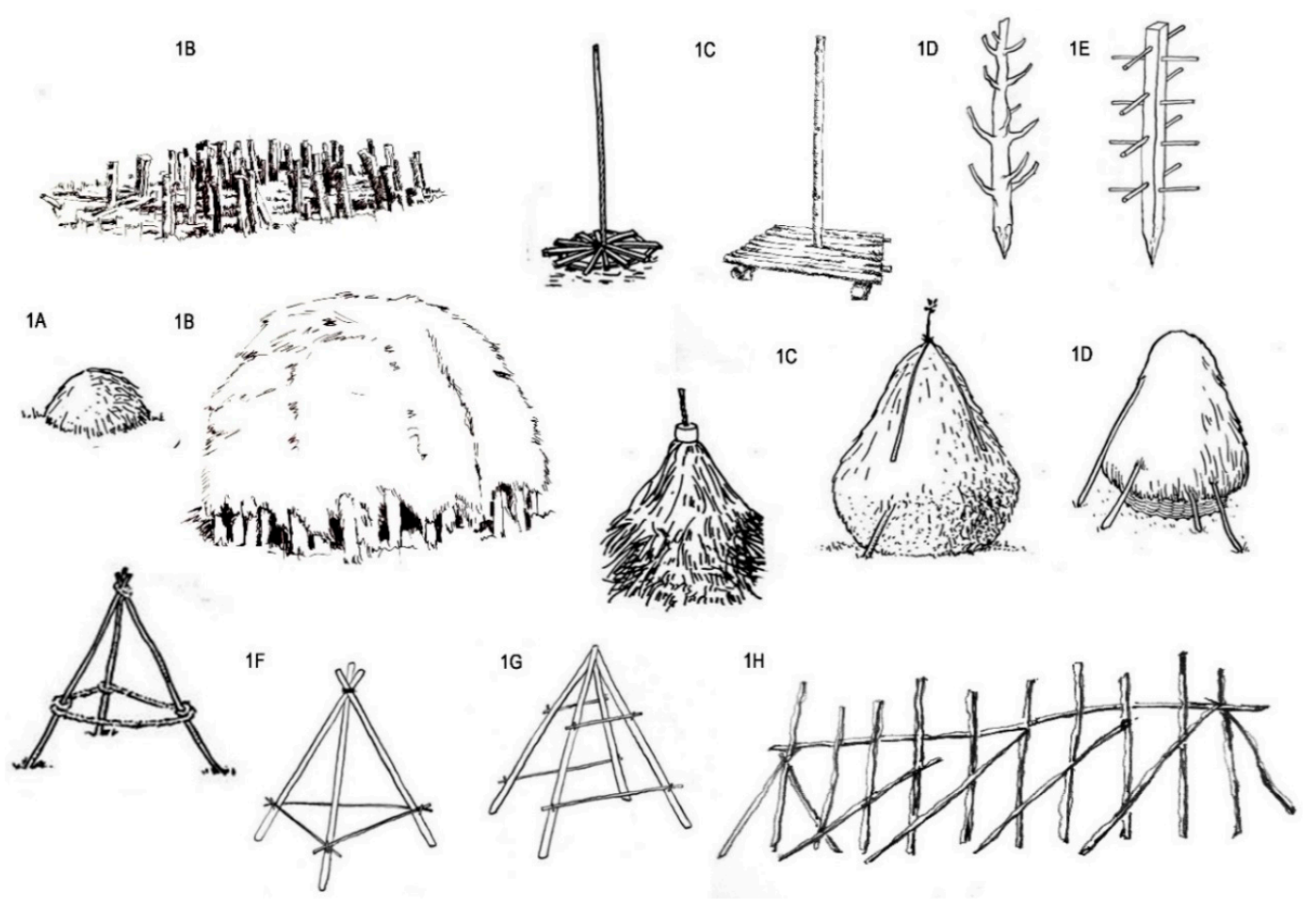

Figure 1. The main types of temporary hay-making structures around Europe. These serve either for drying of grass or for storage of already dried grass/hay, or for both functions (collated by authors). Legend: $1 \mathrm{~A}$ —simple hay heap; $1 \mathrm{~B}$ - hay heap on wooden ped; $1 \mathrm{C}$-haystack with wooden ped; 1D-haystack frame: stake with side branches; $1 \mathrm{E}$ - haystack frame: smooth stake with cross pin; 1F-haystack frame: tripod; $1 \mathrm{G}$-haystack frame: pyramidal stands with multiple horizontal battens, $1 \mathrm{H}$-simple hayracks.

(3) In addition to temporary hayracks or permanent hay barracks, different types of other permanent constructions, including buildings in the hay meadows (thus not within the farm or close to it), for drying and storing hay all year round-single or double stretched hayracks-were widespread in the Alps (Figure 2). In addition to hay drying, these constructions may also serve other purposes, such as storing hay, straw and some other produce, or sheltering farm-carts, agricultural tools, timber, etc. Different variants of hayracks exist, fulfilling these two functions to various degrees. The range of these two functions comprises all the typical versions of hayrack. The function of these structures is the best starting point for classifying hayracks, as it not only explains the several characteristic forms but also relates to their origin and evolution. The hayrack or kozolec (harpfe, arfa, favèr, favàs) is a simple wooden construction for drying hay, retaining an archaic mode of building. The structures have a roof, originally made of straw but, later of wooden, and more recently metal tiles. More than thirty different types can be distinguished on the basis of their construction, most of them found only in Slovenia, the southernmost part of Austria and Northeastern Italy $[37,38]$. In the Dolomites these structures were used for drying fava beans [39]. After Alpine agriculture started specialising in cattle breeding in the beginning of the 20th century, turning arable land into meadows as a consequence, they were used to dry hay. Hayracks on steep slopes are single stretched (Figure 2(3A)), with supports if necessary. Double 
(Figure 2(3B)) or stretched hayracks (Figure 2(3E)) can consist of many "windows", or have a projecting roof attached to one "window" for the protection of carts and people from sudden downpours. Double stretched hayracks (Figure 2(3B-3E)) are built when windy conditions created a need for additional stability. Later, when building techniques advanced, there was a tendency to give outbuildings several economic functions. This resulted in the invention of the linked hayracks "toplarji" to accommodate rational storage of the more abundant and diverse harvest (Figure 2(3C,3D)).

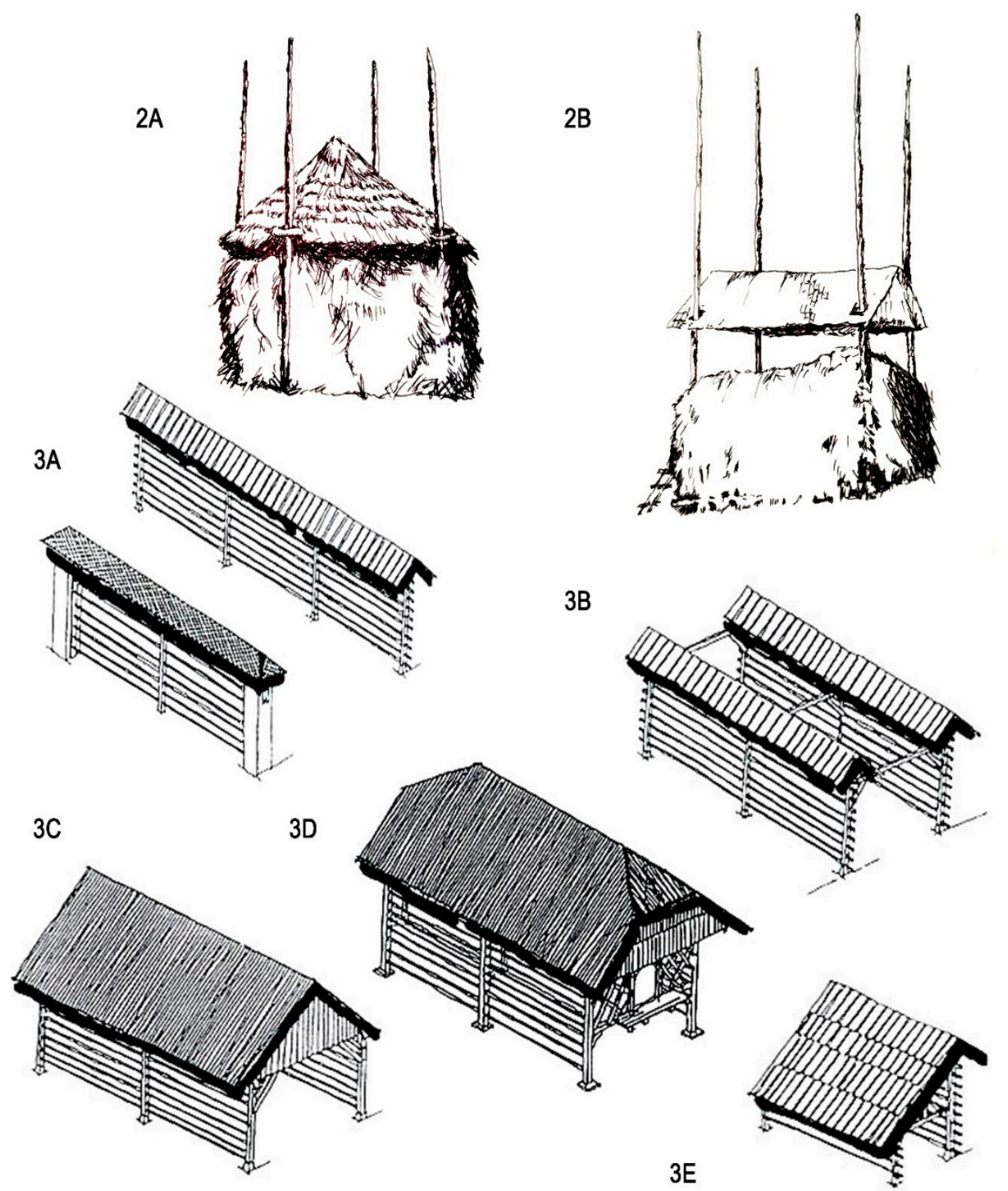

Figure 2. The main types of permanent hayracks and hay barracks around Europe. The installations serve either for drying of grass or for storage of already dried grass/hay, or for both functions (collated by authors). Legend: 2A, 2B-hay barracks of different shapes; $3 \mathrm{~A}$ - single stretched hayrack; 3B-double hayrack, 3C—linked hayracks, 3D—linked hayracks with windows; 3E—stretched hayracks 


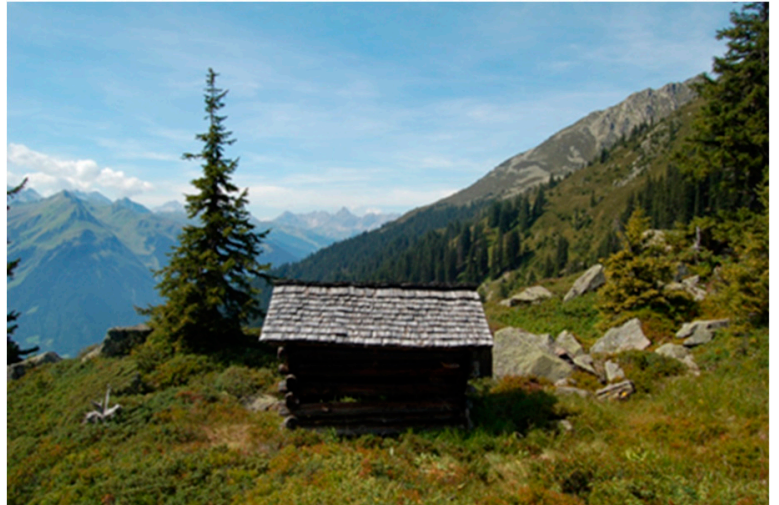

(a)

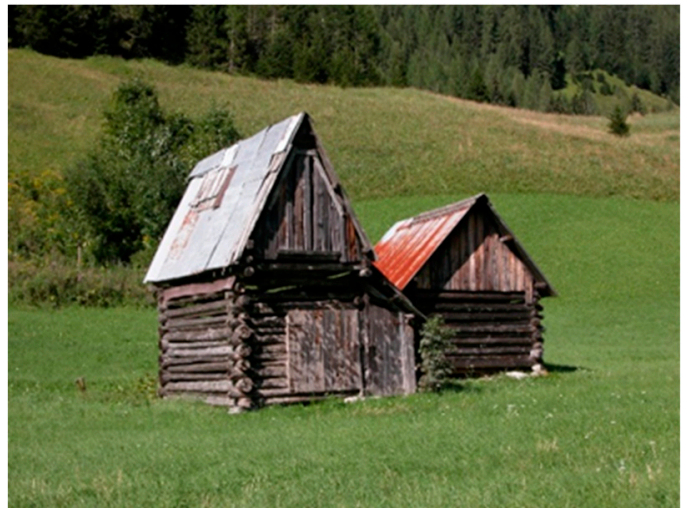

(b)

Figure 3. These "Heubarge" ("baita", "barco") (type 2C) mainly occur in the Alps to serve for hay storage: (a) traditional haylofts, (b) block huts (photos: left: Peter Strasser, right: Viviana Ferrario).

\subsection{The Distribution of Hay-Making Structures}

The present pattern and distribution of different hay-making structures shows the influence of the terrain, whether they are located in mountains or plains, and of the intensity of agriculture (Figure 4). The map was prepared on the basis on the knowledge and observation of the authors, which does not exclude occurrence in other areas of where data was not available. Hay-making structures have mainly been preserved in regions with traditional agricultural landscape on steep slopes and unfavourable conditions for mechanization, e.g., in Austria a few very steep meadows are still mown by hand or only semi-mechanised. In Slovakia traditionally managed meadows have been mainly preserved in mountainous and foothill areas up to $1100 \mathrm{~m}$ a.s.l., and on shallow soils and at steep slopes unsuitable for modern heavy machinery and for intensified meadows during collectivization [40]. They occur mostly as small remnants of mosaic with dispersed settlement, or orchard meadows, or narrow parcels on landscape terraces. Wet meadows have been preserved only as fragments on floodplains in lowlands and valleys, usually as part of areas legally protected as a nature reserve for their valuable habitats. We found a few examples in each study area where hay-making structures are still used, or have been observed over the past 10 years. Most of them have a special local name and are often described as a local curiosity. East and Central Europe, and especially Romania (Maramures and Transylvania in particular) is known for the images of stacks in an overwhelmingly beautiful scenery [41]. Italian haystacks (Italian term $=$ covoni) used to be widespread everywhere in the countryside, both in the mountains and in the lowlands, with different regional names. In Italian Alps structures like baita, barco, and stali are generally found in the highest meadows. They were used to store hay until the snow falls, in order to transport hay by sledge. In the Dolomites, tabià are permanent multifunctional wooden barns (hay drying + storage + cowshed) dispersed on the meadows, to be used in intermediate seasons, often placed along the way to the summer pastures. In the very intensively used and heavily modernised agrarian landscapes of the Netherlands and other parts of North-Western Europe, traditional hay-making has almost disappeared but many of the hay barracks used for it are still preserved by farmers [42]. 


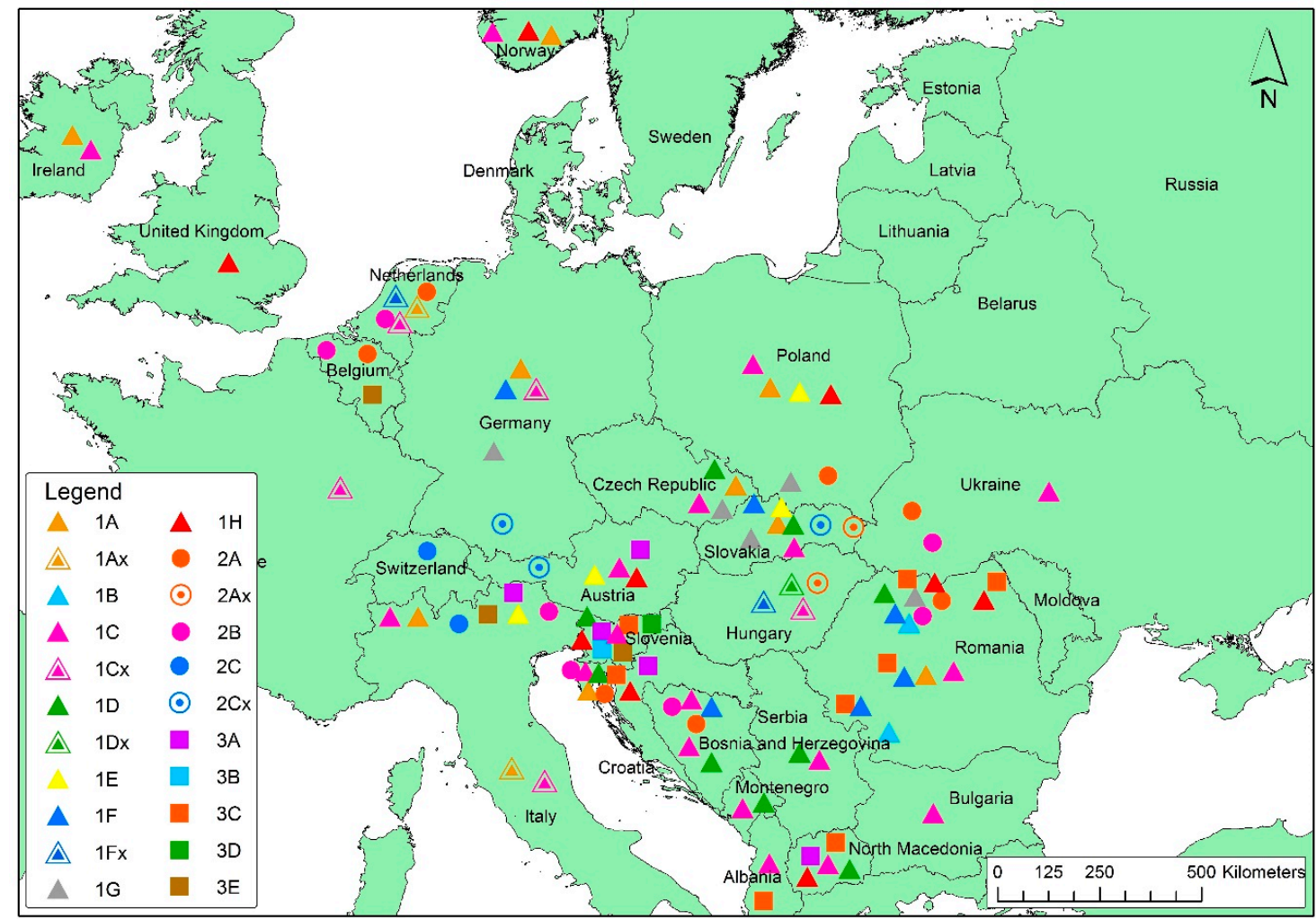

Figure 4. The location of the different types of temporary and semi-temporary hay-making structures in Europe. This map is not exhaustive. It shall serve as a basis for further research and data collection. Legend: The abbreviations of the types of temporary and semi-temporary hay-making structures are as used in Figures 1-3 ("x"-indicates knowledge (historical photograph) of such types used in the past but now extinct, or preserved only in museum)

\subsection{Present and Future of Hay-Making Structures, Their Value}

The most important purpose of hay-making is hay production and its storage for feeding farm animals outside the growing season, particularly in winter. Hay was and is extremely important in several European countries, not only for the abundant dairy cows and, formerly, draught and war horses but also for export. Grass in the peat and clay areas often was, and still is, of excellent quality. Interesting enough, there still exists a thriving hay market, including updated price lists from national and regional commodity exchanges (e.g., The Italian Telematic Commodity Exchange, established by Ministerial Decree n. 97/2012 which is the electronic market for agricultural, agro-energy, agri-food, fish and logistic services). In 2014, Iceland's export of hay to the Faroe Islands (which have insufficient land suitable for local hay production) was five times higher than it had been in 2004 (1500 tons compared 300 tons), Iceland also exports to the European continent. The price for hay is increasing as the European countries produce crops but not enough hay themselves [43].

Compared to intensive high production farming, traditional grassland management has benefits for biodiversity as extensive management helps to maintain the biological genepool. It is important for nature conservation purposes, too. There are special regulations to consider in protected areas, e.g., timing and method of how to cut the hay in a circular way starting from the center of the field, so that animals have a chance to run away.

Traditional hay-making structures are disappearing from the countryside. In the past, they were not only essential to the farming economy but were also very important in social and cultural terms. Hay-making, as a seasonal manual work used bring together farming families of the village, and helped to strengthen family relationship and maintain tradition. Furthermore, the difficult and dangerous transportation of hay from the alpine meadows down to the farm houses in the valleys in January 
was a communal work ("neighbour's assistance") and was followed by a common meal (prepared by women). When the hay was and still is hand-cut without machines and needs to be protected from the adverse weather, the whole family, including children, and the neighbors gather to make hay; and while waiting until the hay was dry, took their ease, sang songs, etc. Harvesting in the high mountains was undertaken in August. The stay of family members - sometimes for some weeks - in the remote meadows far away from the villages was frequently considered as holiday.

In several European regions pre-industrial hay-making structures have a high cultural and aesthetic value. As cultural heritage, they can form part of a national identity (Figure 5). The structures are kept or even used for decorative purposes, even though the hay-making itself has been partly or completely given-up. Structures survive in some regions because they are kept as characteristic landscape elements and in some countries as part of cultural heritage in landscape plans (e.g., in Dolomite World Heritage in the Dolomite landscape, or in regional or local environmental and/or land plans in Slovenia, Austria, Italy and Germany). The structures are considered as a tool for maintaining the identity of the locations, and for supporting tourism and the cohesion and vitality of local communities. The hayrack has become a national icon of the Slovenian landscape. It appears on greeting cards, paintings and photographs, and even postage stamps (Figure 5), and immediately identifies a landscape as Slovenian [31]. Slovenian farmers are usually very proud of their hayracks. Their special attachment to them can be observed in the inscriptions on the dormers or beams, which usually record the year of their construction or the name of the owner. They tell the story of the people who commissioned, constructed or used them [44]. The haystacks have an important aesthetical role for the community in some other mountainous regions of Romania. A perfectly built haystack shows not only that the owner is a hardworking member of the community, but also that he is a very skilled farmer [45].

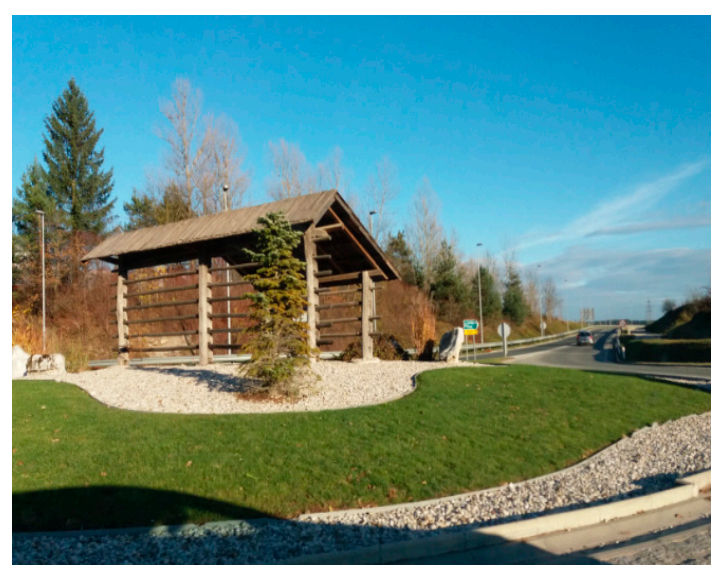

(a)

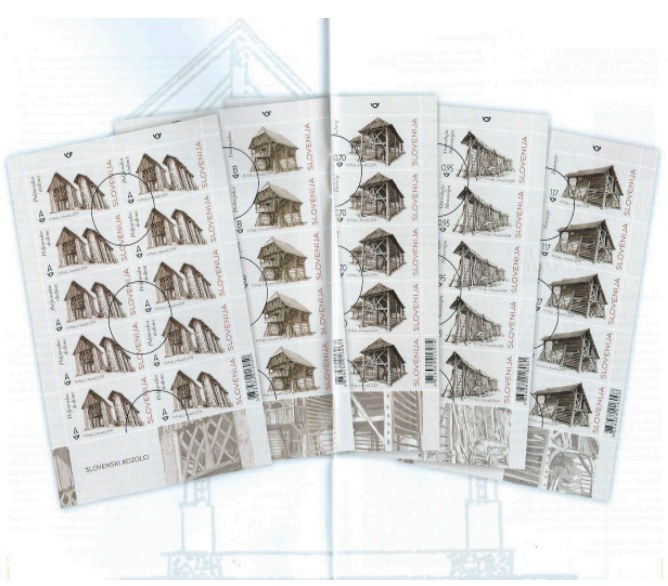

(b)

Figure 5. Hayracks are of national importance in Slovenia. This figure shows the traditional Slovenian kozolec, installed as an aesthetic element in a round-about near Naklo (a) and a new stamp edition (b). (Photos: left: A. Kruse, right: Drago Kladnik).

Information about, and the history and educational value of hay-making structures is presented and promoted by several open-air folk museums across Europe, inspired by the establishment of the Skansen in Stockholn, in 1891. About 250 hayracks are registered in the Slovenian Ethnographic Museum [46]. The first Open-Air Hayrack Museum in the world (named Dežela kozolcev, eng. Land of Hayracks) was opened in Šentrupert in Slovenia in 2013, where old hayracks were re-located and restored [44]. Hayracks are preserved and exhibited also in some other open air museums in Slovenia (e.g., Rogatec, Pleterje, Studor in Bohinj). The hay barrack has been converted for use as a tourist information sign in Poloniny National Park (Slovakia) and is also presented in the Open-Air museum in Humenné (Slovakia). The history of hay-making is documented in the Hooibergmuseum (hay stack museum, the Netherlands) [47] and also in the Hungarian Open-Air Museum near Szentendre. 
The Dimitrie Gusti National Village Museum in Bucharest presents traditional households from Romania and has an almost sacral character, with significant spatial compositional values. Other open-air museums with a significant collection of such structures in Romania are the Astra National Museum Complex from Sibiu and the Maramures Village Museum. In the Swiss canton of Uri there is the theme trail "Wildheuerpfad Rhopaien" (path of the hay makers). The open-air museums are tourist, educational and cultural centers, which often promote rural life and offer expert guided tours, educational workshops, learning by play for children and adults, team-building courses for companies and organisations, exhibitions, concerts, fashion shows and other educational activities.

The great cultural importance of hay becomes obvious when we have a look at the related festivities: hay sculptures, hay processions, hay (and harvest) feasts etc. (Figure 6). Various activities, events and festivals help to maintain and develop the tradition of haymaking and, support the regional development at the same time. Some of many examples are:

- The Lammertaler HayART Festival in Austria, which developed from the traditional Lammertaler hay festival into a famous and very successful art festival. Artists process more than 1 ton of hay to artwork at the world's largest hay sculpture parade, HayART Corso is accompanied by horses, vintage tractors, bands, Schnalzern and costume groups from the Lammertal communities as well as a gourmet and handicraft market. The festival is visited by travelers from other regions or countries (e.g., Germany).

- Hay sculpture exhibition "Fête du Fête du moine" Bellelay/Switzerland; 20.000 visitors within the first month in 2018 [48].

- Many Festivals in Friuli Venezia Giulia Region/Italy, "hay bucking” competitions (for example "Fasin la Mede").

- Cultural heritage related to hay-making also includes a type of folk songs, called "travnice", which were sung on the mountain meadows in Slovakia.

- Competitions in grass cutting (by hand) exist in Hungary, Romania, Slovakia and South Tyrol.

- EtnoTour and many other festivals of grass mowing, using scythes, in Slovenia.

- International Hay-making Festival in Gyimesbükk (Eastern Carpathians, Romania), with the aim to present the landscape of the Gyimes Valley, and the traditional lifestyles of the Csángó people, enabling participants to take part in their traditional hay-making activities.

Many permanent hay-making constructions have now been repurposed for new uses, such as storage of other materials, or have been rebuilt as hay hotels, holiday flats, or apartments or houses for living. There are several examples of hay hotels in Germany (e.g., East Frisia) or holiday flats in Switzerland (e.g., Engadin). Nowadays, increasing nostalgia is causing the hay barracks to return or be rebuilt in places such as Belgium or Romania. As part of tourism development in this area, special marketing programs are offered to visitors; in Austria the subjects of such programs include hay cheese, hay milk, hay tee; and "retro-activities" (e.g., hay-making recorded for TV, oral history).

Many stories are told about hay and hay barracks (especially in the Netherlands, Romania) and the latter have played a significant role in (painted) art since the 16th century. The hayfield is a picturesque arena of communal, seasonal work, which is visually very attractive and has inspired many artists. It was a favorite feature of rural landscape paintings. Many people and organisations in online communities are active in the field of hay and arts, including literature, painting, architecture, archaeology, photography or a combination thereof. A world portal for friends of hay and culture was set up by the Foundation for Preserving the Knowledge of the Dutch Hay Barrack, whose website presents information on museums, organisations, events and notable persons, and artistic depictions of the Dutch hay barrack and the hay-making process [49]. A collection of artworks made of hay, currently with over 6500 items is presented on the web portal "Hay in art", and contains works of art and documentary photographs, both amateur and professional [50]. The art database offers options to search and sort works by artist, country, date of work, and for essays theme (e.g., hay in winter; hay on water; different roles of hay-play or work; etc.). 
Even nowadays, hay-making structures and hay meadows are well known to and highly appreciated by the public. They are popular as scenery (or accommodation) for weddings or other special events, and in picture calendars. Hay is often used for decoration of village entrances, and for gifts and flower combinations, especially for thanks giving celebrations. The "Nature in the City" project of Transylvanian artist Ernő Bartha, consisting of performances and large-sized hay structures also had the aim to reconnect urban dwellers with traditions and organic materials, like hay [51].

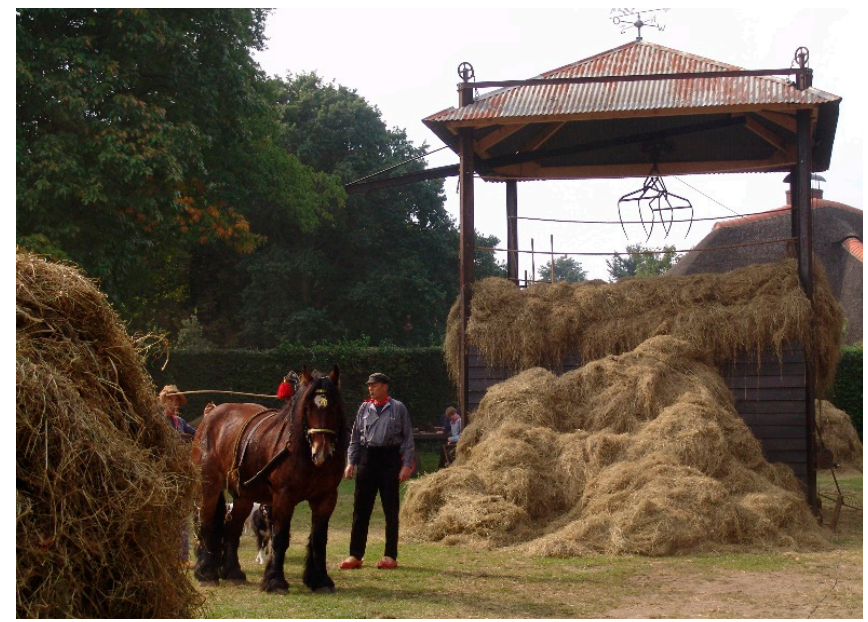

(a)

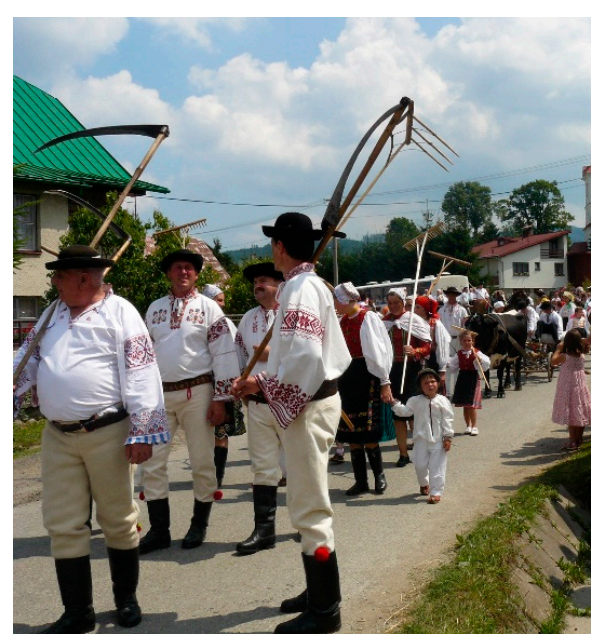

(b)

Figure 6. In the rural countryside, hay sculptures are becoming famous, either as a matter of regional identity, to convey a message (most often against the creation of regional parks or against infrastructure projects), or in connection to festivities. Traditional and new festivals involving hay are maintained. (a) Harvest festival/Netherlands, 2008; (b) Festival in Liptovská Teplička/Slovakia, 2009. (Photos: left: Susan Jurgens, right: Jana Špulerová).

\section{Discussion}

Hay-making structures used to be common all over Europe, and although there are regional types and differences, there are also many parallels and commonalities. The geographical distribution of hay-making structures, similarly like other aerial drying sheds e.g., for maize, is related to the climatic and geological factors of these areas, as well as being influenced by tradition [28]. Hay barracks are still very common in the Dutch countryside [34,36,52-56] and they are ubiquitous in Dutch art. Most studies and books on hay-making structures come from Slovenia $[31,37,38,44]$, where these structures are still widespread and which is (with good reason) sometimes called "the land of the hayrack". On the other hand, they are rarely used for actually storing hay at present, and the permanent hay-making structures in particular have been repurposed to other uses. In spite of that, they are still generally esteemed as a national symbol of high cultural value.

Due to mechanisation, decreasing livestock production as a result of declining price of milk, traditional hay-making structures are disappearing from most of the regions of Europe. We can therefore consider hay-making "by hand" an intangible cultural heritage [57]. Speaking very generally, we find hay-making structures, wherever intensified, mechanised grass harvest is either technically or economically infeasible. This is the reason why these structures today are most common on marginal agricultural land, especially in mountain areas turning an economic disadvantage into a cultural advantage in some countries [58]. In countries other than Slovenia, the typical temporary hay-making structures are characterised by simpler constructions. The natural and manmade landscapes, which are so popular with visual artists and landscape architects, are often just a reflection of people's hard work [59], so it is unsurprising that farmers will introduce labour-saving mechanization is available.

Across Europe, concerns are rising over the loss of traditional ecological knowledge as agricultural communities continue to abandon traditional practices. These sources can play an important role in 
complementing and validating our understanding of traditional management systems [60]. Romania stands out among the members of the European Union for the diversity and richness of its natural environment and cultural traditions, with large areas of the mountain regions covered by pastures and hay meadows. The need to preserve the traditions and the cultural and natural patrimony of the mountain areas is one of the conclusions of the conference in 2010, "Mountain hay meadows-hotspots of biodiversity and traditional culture" [61].

Consideration of hay-making structures implies consideration of meadows as agro-ecosystems. Agro-pastoral decline in European mountain areas has, in recent times, caused changes to traditional landscapes with negative consequences for semi-natural grassland conservation and the associated biodiversity and ecosystem services [62]. In the Italian Alps, grassland patches enclosed in a forest matrix are progressively disappearing [63].

A review of Sweden and the Baltic region from a historical landscape perspective, focusing on the management of semi-natural grasslands and the perception of "natural" vs. "cultural" landscapes, concluded that semi-natural grasslands are today a matter of high concern from conservation point of view $[57,64]$. Similarly to other countries, such as Hungary and Slovakia, one applicable solution for the maintenance of semi-natural grasslands was land acquisition of protected sites and accession of funds for conservation measures from different sources (e.g., LIFE, national grants) [65]. In the White Carpathians (Slovakia) important areas have been purchased by nature conservation authorities and restored to species-rich hay meadows [66]. Because of the declines in grassland bird populations across North America, many State and federal agencies are making efforts to gear management towards preservation of grassland bird populations, particularly in a landscape context $[67,68]$. Understanding existing traditional grassland management could greatly help to improve the ability to preserve biodiversity and cultural value in traditionally managed farmlands, which could be supported by subsidies $[4,69]$.

A greater awareness of traditional hay-making structures may help to increase inhabitants, visitors and readers' appreciation for their countries' rich agricultural and architectural legacy. Contemporary and historic photographs and other images, and various promotional activities, can provide historical, cultural, and economic context for understanding the rural landscape [70]. Today many activities are being undertaken to revive the tradition of hay-making due to the high cultural, historical, aesthetic, educational, scientific, inspirational and recreational value associated with it.

\section{Conclusions}

In this article, we have described the broad range of hay-making structures, which has been developed and used in Europe over the centuries and discussed their current state of preservation. In mountain areas, the hay-making structures and rural buildings dedicated to drying and storage of grass and other products, as well as the permanent meadows which usually form their immediate environment, are an essential part of the rural heritage. Since the landscape was being shaped by the co-evolution of nature and human activities, its anthropogenic and environmental components must be considered together in an integrated fashion in landscape evaluation, management and development. From a structural and functional standpoint, this implies considering the hay-making structures in conjunction with the elements of the associated agro-ecosystems.

Although hay-making is of minor economic importance in many regions nowadays, it still has a high significance for people. Nearly everybody has some ideas of or a feeling about hay-making - either from their own experience or via traditions and impressions handed on by family, acquaintances or the general culture. Thus, we may speak of an intangible heritage of hay-making. However hay-making is related to tangible structures, permanent, semi-permanent or temporary. Many of these have cultural importance, and in some countries are even part of the national heritage. This is probably one of the main reasons why they have not disappeared completely.

In light of this, it is astonishing to find that many countries do not maintain any form of register or catalogues on the subject. While detailed descriptions and inventories can be found in Slovenia 
(land of the hay racks- “Dežela kozolcev"), and an inventory of the Maiensäße in Montafon, a region of Austria was made recently, in most countries the information about and knowledge of the different kinds of hay-making structures, and in particular the temporary and semi-permanent ones is vanishing. The authors therefore plan to prepare a second article, focusing on a collection of examples from various nations (mainly presented as photographs) of types of hay-making and depositing structures and related methods (contributions are welcome, please contact: secretariat@eucaland.net).

Author Contributions: Members of EUCALAND network ("European Culture expressed in Agricultural Landscapes") from different European countries conducted this work. All co-authors collected, prepared and analysed the data; J.Š. and A.K. conceptualized and wrote the manuscript with inputs of other co-authors; D.Š. produced map (Figure 4) based on data provided by network partners; S.J. helped with supervision and all co-authors with final review.

Funding: This work was supported by the Scientific Grant Agency of Ministry of Education of the Slovak Republic [No. 2/0078/18 "Research of biocultural values of landscape"]. Work at NIBIO was financed by the Norwegian Ministry of Agriculture and Food, through the Research Council of Norway [grant no. 194051].

Acknowledgments: We would also like to thank James Asher for English proofreading.

Conflicts of Interest: The authors declare no conflict of interest.

\section{References}

1. Lesschen, J.P.; Elbersen, B.; Hazeu, G.; van Doorn, A.; Mucher, S.; Velthof, G. Task 1-Defining and Classifying Grasslands in Europe. In Final Report March 2014; Alterra, Part of Wageningen UR: Wageningen, The Netherlands, 2014.

2. Hoffbeck, S.R. The Haymakers: A Chronicle of Five Farm Families, 1st ed.; Minnesota Historical Society Press: St. Paul, MN, USA, 2002; p. 223.

3. Ivașcu, C.M.; Öllerer, K.; Rákosy, L. The Traditional Perceptions of Hay and Hay-Meadow Management in a Historical Village from Maramureş County, Romania. Martor J. 2016, 21, 39-51.

4. Babai, D.; Molnar, Z. Small-scale traditional management of highly species-rich grasslands in the Carpathians. Agric. Ecosyst. Environ. 2014, 182, 123-130. [CrossRef]

5. Glasenapp, M.; Thornton, T.F. Traditional ecological knowledge of Swiss Alpine farmers and their resilience to socioecological change. Hum. Ecol. 2011, 39, 769-781. [CrossRef]

6. Gingrich, S.; Krausmann, F. At the core of the socio-ecological transition: Agroecosystem energy fluxes in Austria 1830-2010. Sci. Total Environ. 2018, 645, 119-129. [CrossRef] [PubMed]

7. Baessler, C.; Klotz, S. Effects of changes in agricultural land-use on landscape structure and arable weed vegetation over the last 50 years. Agric. Ecosyst. Environ. 2006, 115, 43-50. [CrossRef]

8. Bezák, P.; Mitchley, J. Drivers of change in mountain farming in Slovakia: From socialist collectivization to the common agricultural policy. Reg. Environ. Chang. 2014, 14, 1343-1356. [CrossRef]

9. Bicik, I.; Jelecek, L.; Stepanek, V. Land-use changes and their social driving forces in Czechia in the 19th and 20th centuries. Land Use Pol. 2001, 18, 65-73. [CrossRef]

10. Druga, M.; Faltan, V. Influences of Environmental Drivers on Land Cover Structure and Its Long-Term Changes: A Case Study of the Villages of Malachov and Podkonice in Slovakia. Morav. Geogr. Rep. 2014, 22, 29-41.

11. Gerard, F.; Petit, S.; Smith, G.; Thomson, A.; Brown, N.; Manchester, S.; Wadsworth, R.; Bugar, G.; Halada, L.; Bezák, P.; et al. Land cover change in Europe between 1950 and 2000 determined employing aerial photography. Prog. Phys. Geogr. 2010, 34, 183-205. [CrossRef]

12. Finch, H.J.S.; Samuel, A.M.; Lane, G.P.F. Conservation of grass and forage crops. Lockhart E Wiseman's Crop Husbandry Including Grassland, 9th ed.; Finch, H.J.S., Samuel, A.M., Lane, G.P.F., Eds.; Woodhead Publishing: Sawston, UK, 2014; pp. 513-526.

13. Südtirol News. Österreich: Heumilch 2017 deutlich stärker als Gesamtmarkt gewachsen. Südtirol News, 30 January 2018.

14. EUCALAND, About|FEAL EAtlas. 2017. Available online: http://feal-future.org/eatlas/en/node/17 (accessed on 29 November 2018). 
15. Centeri, C.; Renes, H.; Roth, M.; Kruse, A.; Eiter, S.; Kapfer, J.; Santoro, A.; Agnoletti, M.; Emanueli, F.; Sigura, M.; et al. Wooded Grasslands as Part of the European Agricultural Heritage. In Biocultural Diversity in Europe; Agnoletti, M., Emanueli, F., Eds.; Springer International Publishing: Berlin/Heidelberg, Germany, 2016; pp. 75-103.

16. Imrichová, Z. Impact of management practices on diversity of grasslands in agricultural region of middle Slovakia. Ekologia (Bratislava) 2006, 25, 76-84.

17. Cvitanovic, M.; Lucev, I.; Furst-Bjelis, B.; Borcic, L.S.; Horvat, S.; Valozic, L. Analyzing post-socialist grassland conversion in a traditional agricultural landscape-Case study Croatia. J. Rural Stud. 2017, 51, 53-63. [CrossRef]

18. Halabuk, A.; Mojses, M.; Halabuk, M.; David, S. Towards Detection of Cutting in Hay Meadows by Using of NDVI and EVI Time Series. Remote Sens. 2015, 7, 6107-6132. [CrossRef]

19. EUROSTA Land Cover Overview by NUTS 2 Regions. Eurostat-Data Explorer. 2015. Available online: http://appsso.eurostat.ec.europa.eu/nui/submitViewTableAction.do (accessed on 9 May 2019).

20. Feranec, J.; Soukup, T.; Hazeu, G.; Jaffrain, G. European Landscape Dynamics: CORINE Land Cover Data; CRC Press: Boca Raton, FL, USA; Taylor \& Francis Group: Abingdon, UK, 2016; p. 337.

21. EEA. Biogeographical Regions, European Environment Agency. 2016. Available online: https://www.eea. europa.eu/data-and-maps/data/biogeographical-regions-europe-3 (accessed on 30 November 2018).

22. Zimmermann, W. The 'helm' in England, Wales, Scandinavia and North America. Vernac. Archit. 1992, 23, 34-43. [CrossRef]

23. Kovač, M. Istrian Cattle; v Štifanić, A., Kovač, M., Eds.; Istrian Cattle a Monograph: Višnjan, Croatia, 1999; pp. 24-29.

24. Bassetti, S.; Morello, P. Paesaggio e Architettura Rurale Nelle Valli Ladine Delle Dolomiti; Banca di Trento e Bolzano: Trento, Italy, 1983.

25. Gellner, E. Architettura Rurale Nelle Dolomiti Venete; Dolomiti: Cortina, Italy, 1988.

26. Bele, B.; Norderhaug, A. Traditional land use of the boreal forest landscape: Examples from Lierne, Nord-Trøndelag, Norway. Nor. Geogr. Tidsskr. Norsk. Geogr. Tidsskr. 2013, 67, 12-23. [CrossRef]

27. Važanová, J. Review of Trávnice. Lúčne piesne na Slovensku: Ku genéze, štruktúre a premenám piesňového žánru [Trávnice. The Meadow Songs in Slovakia: A Contribution to the Origins, Structure, and Transformations of a Song Genre], Hana Urbancová. World Music 2009, 51, 162-165.

28. Bujanda Miguel, M. Varieties of maize aerial drying sheds across Europe. Arhit. Raziskave Archit. Res. 2014, 1, 27-36.

29. Evensen, H.P.E. Slå Med Ljå; Sollia Forlag: Oslo, Norway, 2015.

30. Juvanec, B. Kozolec; Fakulteta za arhitekturo: Ljubljana, Slovenia, 2007; p. 116.

31. Mušič, M. The Architecture of the Slovene "kozolec" (hay rack). Architektura Slovenskega Kozolca; Cankarjeva založba: Ljubljana, Slovenia, 1970; p. 165.

32. Podolák, J. Pestovanie pol'nohospodárskych plodín a chov hospodárskych zvierat na Slovensku od polovice 19. do polovice 20. storočia. Agrikultúra 1965, 4, 29-77.

33. Skre, B.G. Havråboka—Soga om ein Gamal Gard på Osterøy; Stiftinga Havråtunet: Osterøy, Norway, $1994 ;$ p. 173.

34. Jurgens, S.M. Paalschuren in Vlaanderen. Land Zicht 2006, 75, 38-45.

35. Harvey, N. A History of Farm Buildings in England and Wales; David \& Charles: Newton Abbot, UK, 1984; p. 279.

36. Jurgens, S.M. A Terminological Approach to the History and Dissemination of Hay Barracks and Stacks. 2019 , in press.

37. Melik, A. Kozolec na Slovenskem; Znanstveno društvo: Ljubljana, Slovenia, 1931; p. 107.

38. Čop, J.; Cevc, T. The path of cultural heritage. Slovenski Kozelec. Slovene hay-rack, Book Series; AGENS d.o.o. Žirovnica: Žirovnica, Slovenija, 1993; p. 239.

39. Baragiola, A. La Casa Villereccia delle Colonie Tedesche del Gruppo Carnico Sappada, Sauris Timau, con Raffronti delle Zone Contermini Italiana e Austriaca Carnia, Cadore, Zoldano, Agordino, Carintia e Tirolo; Drucker: Padova, Italy, 1915.

40. Lieskovský, J.; Kenderessy, P.; Špulerová, J.; Lieskovský, T.; Koleda, P.; Kienast, F.; Gimmi, U. Factors affecting the persistence of traditional agricultural landscapes in Slovakia during the collectivization of agriculture. Landsc. Ecol. 2014, 29, 867-877. [CrossRef] 
41. Nicolson, A. Hay. Beautiful. National Geographic Magazine. 2013. Available online: https://www. nationalgeographic.com/magazine/2013/07/transylvania-hay/ (accessed on 18 December 2018).

42. Balassa, I.; Ortutay, G. Hungarian Ethnography and Folklore; Corvina: Budapest, Hungary, 1979; p. 747.

43. Iceland Review. Heuexport verfünffacht. Iceland Review, 29 September 2014.

44. Žarkovič, V. The Land of Hayracks. The First Open-Air Hayrack Museum in the World. 2012. Available online: http://www.slovenia.si/culture/tradition/the-land-of-hayracks (accessed on 4 January 2019).

45. Negraru, A.; Sima, E.; Iuga, A. Fânul ca element de patrimoniu în satul Șurdești. Între tradiție și modernitate. (Hay as element of heritage in the village Șurdești. Between tradition and modernity). Cybela 2005, 1, 44-47.

46. Slovenski Etnografski Muzej. Kozolec|Slovenski Etnografski Muzej. 2019. Available online: https: //www.etno-muzej.si/en/digitalne-zbirke/kljucne-besede/kozolec (accessed on 4 January 2019).

47. Stichting Kennisbehoud Hooibergen Nederland. 2016. Available online: https://www.hooidelta.nl (accessed on 7 July 2019).

48. Tausende Besuchen Heuskulpturen-Ausstellung. Landwirtschaftlicher Informationsdienst LID.CH. 2018. Available online: https://www.lid.ch/agronews/detail/news/tausende-besuchen-heuskulpturen-ausstellung/ (accessed on 1 July 2019).

49. Stichting Kennisbehoud Hooibergen Nederland. Het Nederlands Hooiberg Museum. On line Haymusea and Foundations in the World. 2016. Available online: http://www.hooiberg.info/?page=hayworld (accessed on 18 December 2018).

50. Ritch, A. Hay in Art: Introduction to the Hayinart Database. 2004. Available online: http://www.hayinart. com/000319.html (accessed on 30 November 2018).

51. Bartha, E. Nature in the City. Martor 2016, 21, 188-194.

52. Jarvis, D.G. Hay Barracks in Newfoundland. Mater. Cult. Rev. 2013, 77/78, 171-179.

53. Jurgens, S.M. Paalschuren in Vlaanderen en Wallonië. Land Zicht 2007, 76, 26-28.

54. Jurgens, S.M. Hooibergen en vloedschuren in het Gelders rivierengebied. His-Torisch-Geogr. Tijdschr. 1993, $11,41-52$.

55. Noble, A.G. The Hay Barrack: Form and Function of a Relict Landscape Feature. J. Cult. Geogr. 1985, 5, 107-116. [CrossRef]

56. Iuga, A. Intangible hay heritage in Șurdești. Martor 2016, 21, 67-84.

57. Dahlström, A.; Iuga, A.; Lennartsson, T. Managing biodiversity rich hay meadows in the EU: A comparison of Swedish and Romanian grasslands. Environ. Conserv. 2013, 40, 194-205.

58. Kruse, A.; Paulowitz, B. UNESCO World Heritage as an opportunity for mountain landscapes - a trigger for development not only in the Alps. TÁJÖKOLÓGIAI LAPOK J. Landsc. Ecol. 2018, 41-57.

59. Raducan, V. Land Art and Agriculture. Sci. Pap.-Ser. B-Hortic. 2012, 56, 381-388.

60. Burton, R.J.F.; Riley, M. Traditional Ecological Knowledge from the internet? The case of hay meadows in Europe. Land Use Pol. 2018, 70, 334-346. [CrossRef]

61. Caluseru, A.L.; Cojocariu, L.; Borlea, F.; Bordean, D.-M.; Horablaga, A. Rural Development of Mountain Areas in Romania, Challenges and Targets for the Year 2020. In Ecology, Economics, Education and Legislation, Volume II; Stef92 Technology Ltd.: Sofia, Bulgaria, 2015; pp. 791-797.

62. Knowles, B. Mountain Hay Meadows: Hotspots of Biodiversity and Traditional Culture. Society of Biology, London. Pogány-havas Association. 2011. Available online: https://www.mountainhaymeadows.eu/online_ publication/ (accessed on 18 December 2018).

63. Orlandi, S.; Probo, M.; Sitzia, T.; Trentanovi, G.; Garbarino, M.; Lombardi, G.; Lonati, M. Environmental and land use determinants of grassland patch diversity in the western and eastern Alps under agro-pastoral abandonment. Biodivers. Conserv. 2016, 25, 275-293. [CrossRef]

64. Eriksson, O.; Cousins, S.A.O. Historical Landscape Perspectives on Grasslands in Sweden and the Baltic Region. Land 2014, 3, 300-321. [CrossRef]

65. Balázsi, Á. Grassland management in protected areas-Implementation of the EU biodiversity strategy in certain post-communist countries. Hacquetia 2018, 17, 73-84. [CrossRef]

66. Jongepierova, I.; Mitchley, J.; Tzanopoulos, J. A field experiment to recreate species rich hay meadows using regional seed mixtures. Biol. Conserv. 2007, 139, 297-305. [CrossRef]

67. Kirk, D.A.; Lindsay, K.E.; Brook, R.W. Risk of Agricultural Practices and Habitat Change to Farmland Birds. Avian Conserv. Ecol. 2011, 6, 5. [CrossRef] 
68. Ribic, C.A.; Guzy, M.J.; Sample, D.W. Grassland Bird Use of Remnant Prairie and Conservation Reserve Program Fields in an Agricultural Landscape in Wisconsin. Am. Midl. Nat. 2009, 161, 110-122. [CrossRef]

69. Belcakova, I.; Gazzola, P.; Pauditsova, E. Public Participation and Sustainable Landscape Management. In Landscape Impact Assessment in Planning Processes; Walter De Gruyter Gmbh: Berlin, Germany, 2018; pp. 112-138.

70. Falk, C.G. Barns of New York: Rural Architecture of the Empire State; Cornell University Press: Ithaca, NY, USA, 2012; p. 298.

(C) 2019 by the authors. Licensee MDPI, Basel, Switzerland. This article is an open access article distributed under the terms and conditions of the Creative Commons Attribution (CC BY) license (http://creativecommons.org/licenses/by/4.0/). 